\title{
Training highly qualified personnel for professional activities in the context of digital learning
}

\author{
T.Yu. Gvildis ${ }^{1 *}$ \\ ${ }^{1}$ Scientific Center for Robotics and Technical Cybernetics, Saint Petersburg, Russia
}

\begin{abstract}
The article actualizes the solution of the problem of highly qualified teaching staff "Researcher. Lecturer - researcher" in the system of continuing education to carry out professional activities in the conditions of the emerging digital educational environment and presents the main components of a multi-level system of training lecturers for professional activities in the conditions of digital education. In developed countries of Europe, graduates of the third stage of higher education, who are awarded the degree of doctor of philosophy $(\mathrm{PhD})$ at the end of their studies, are the main players in the field of forming a "knowledge society", which is distinguished by a departure from template solutions in various fields of activity.
\end{abstract}

\section{A problem statement}

The intensive growth of scientific knowledge and the rapid pace of economic changes experienced by modern society make new demands on the professional training and personal development of teachers.

Education, as a sector of the economy and social activity, is aimed at using the Internet environment, empowering teachers to create and exchange new ideas in the educational sphere and integrating information and telecommunication technologies with real economic processes.

The government of the Russian Federation approved the priority project in the field of education "Modern digital educational environment in the Russian Federation" as a part of the state program "Development of education" for 2018-2025. The project is aimed at solving the problem of increasing the country's competitiveness by training competent personnel for the development of the digital economy in Russia.

The key role of digital technologies is in the innovative development of higher education, namely, in preparing future lecturers being ready to work in a digital educational environment. This direction is implemented through the Federal project "Personnel for the digital economy of the Russian Federation" of the national program "Digital economy of the Russian Federation" .The goal of the project is to form a new personality of a teacher who is able to improve and is ready to solve the problems of professional activity.

*Corresponding author: ipcs-profped@yandex.ru 
Science plays an important role in solving global problems of our time. Pedagogy as a science has passed a long way of development, becoming a science in the XX century, when the subject and methods of its research were distinguished, a categorical apparatus was formed. V.A. Slastenin calls pedagogy a science that studies "the essence, laws, trends and prospects of the development of the pedagogical process (education) as a factor and means of human development throughout his life" [1].

It is necessary to follow the leading trends in the development of modern education: global, national, and regional. The leading trends in the development of modern education include the following: continuity of education, humanization and humanitarization, democratization; integration, intensification, digitalization.

In education, digitalization is aimed at ensuring the continuity of the learning process, the so-called lifelong learning, as well as its individualization based on advanced learning technologies.

Continuing education is carried out based on the use of the digital educational environment (DEE) in digital learning. It is the process and result of interaction between subjects and objects of education, accompanied by the creation and expansion of the educational environment, the specifics of which are determined by these objects and subjects. DEE is created only by those objects and subjects that participate in the educational process, and not by classrooms, textbooks, or technical means. This highlights the humanitarian nature of education [2].

The development of postgraduate studies as the third level of higher education, the creation of a new culture of postgraduate training in the context of the growing complexity of intellectual activity and the strengthening of global competition in education are possible only with rapid adaptation to new challenges and changing requirements of the labor market. Today, in addition to the function of training personnel for science and higher education, postgraduate studies solve problems related to the request for specialists with the highest level of research education in various fields of intellectual activity, i.e. directly participate in the processes of building up the intellectual potential of the domestic economy and social sphere.

\subsection{The objective of the work}

The methodological basis of this research is based on conceptual ideas about the digitalization of the economy as a process of mass distribution of digital technologies in society, and their determining influence on the entire socio - economic development of the country, its technological structure and forms of public relations, including activities related to training personnel [6].

In the context of digitalization of education, the number of studies devoted to training in the framework of the DEE has increased (A.A. Konovalov, O.V. Mikhaleva, V.K. Obydenkova, S.R. Khablieva, M.S. Yanitsky) [3-4].

Research on digital learning, digital educational environment, and the specifics of organizing training in a new format in Russian pedagogical science and practice was preceded by the study of the problems of informatization and the formation of the information environment by a group of scientists led by I.V. Robert [5-7]. The analysis of works aimed at solving certain aspects of this problem has shown that: on a methodological level, the essence and features of the organization of continuing education are revealed (A.A. Verbitsky, A.P. Vladislavlev, A.V. Darinsky, V.P. Zinchenko, A.M. Novikov, etc.) [8-12].; on a theoretical level: some aspects of organization, maintenance, training with use of information technologies are considered in the research by E.S. Polat (requirements for training teachers in the use of distance learning); S.D. Karakozov (especially teaching and learning technologies in the system of distance education) [13]; I.F. Berezhnoy (problems 
of teaching pedagogical forecasting) [14-15]. Some aspects of the problem are considered in the works by A.L. Galinovsky (improving the training system using computer information technologies); M.B. Lebedeva (modular professional training of future teachers to use information technologies in school); N.V. Nikulicheva (organizational and pedagogical support for teachers in the system of advanced training) and others[16]. However, it should be noted that we have not been able to find methodologically sound, systemically developed and scientifically meaningful theoretical foundations for training teachers for professional activities in the emerging digital learning environment that meets the requirements of a digital society.

\section{Materials and the results of the research}

At the same time, there is a need to apply a scientific approach to the analysis of the existing system of training highly qualified personnel in order to assess its compliance with the goals and objectives of the National program, determine the necessary changes and develop methods aimed at improving the effectiveness of training specialists.

The purpose of the study is to assess the current situation and identify key problems in staffing the implementation of the National program "Digital economy of the Russian Federation", as well as to determine the main directions of their possible solutions.

To identify the theoretical and methodological foundations that allow to systematically study the training of highly qualified lecturers for professional activities in the conditions of digital learning.

To consider the principles and conceptual ideas of the situation, the idea of lifelong education; the idea of modular building program; the idea focus on the development and formation of individual capital, the development potential of the individual; the principle of homomorphism, the similarity of the subject of the upcoming activities in the digital educational environment; the principle of fractal dimensions; the idea of professional and pedagogical quality; the principle of dualism, the selection information "from the past" and "future"; the principle of diversifying content, growing diversity.

Creating conditions for graduate students to acquire and test the competencies that are part of the professional competence of a teacher in conditions that model professional activity in digital education; developing skills to describe, analyze, and predict pedagogical phenomena in digital education and gaining experience in analyzing professional and educational problem situations and solving pedagogical problems; acquisition of constructive communication skills in conditions that model professional activity in the framework of digital education, individual and joint decisions; acquisition of the ability to reflect on their own cognitive and professional activities.

The key role of digital technologies is in the innovative development of higher education, namely, in preparing future lecturers being ready to work in a digital educational environment.

Training teaching staff for professional activity in the conditions of digital learning is understood as training personnel continuously at all levels of training, taking into account the specifics of the formation of ways to organize the educational process:

- at the bachelor's program level - formation of an understanding of the organization of digital education, the structure of activities in the electronic information educational environment, motivation for professional activity, knowledge about the legal support of the educational process using e-learning and distance learning technologies; methods, techniques and tools implemented in digital education; technologies for organizing training in the distance learning system, on mass open online courses; 
- at the master's degree program level - training in the technology of organizing training by using the means of the digital educational environment; systematization of existing knowledge and experience; dissemination of positive practices in digital education;

- at the $\mathrm{PhD}$ degree program level - organization of analytical activities using the tools of the digital educational environment [17-19].

The legislative change in the status of training scientific and pedagogical personnel, namely, the allocation of such training to a separate, third level of higher education, determines the need to take into account those trends, problems, contradictions, and innovative changes that are characteristic of Russian higher schools in general when selecting the content, technologies, forms of training. In this regard, it is important to take into account the factors of transition to a new generation of educational standards, their unambiguous link with professional standards, the intensification of the educational process through the use of digital technologies, increasing the requirements and the role of employers in training specialists, etc.

These requirements are formulated in the form of universal (key, supra-professional), general professional, as well as professional (subject-specialized) competencies that complement their requirements for the quality of the individual, the expression of the personality's social properties. The competence screen of a modern higher school graduate includes a wide range of competencies, including: social interaction competencies; systemactivity competencies; self-organization and self-management competencies; valuesemantic and political-legal competencies; competences of independent cognitive activity, digital competences. All this highlights the importance of designing a learning content that guarantees the formation of such a diverse range of competencies [20].

The competence approach in the DEE serves as a purposeful ideology and methodology for the formation of universal and professional competencies for solving situations at the level of IS and DEE technologies, and covers the ability, readiness for cognition and relationships being necessary for performing professional activities within the DEE [21].

Accordingly, the main goal of using the competence approach in training lecturers is to cultivate a competent specialist to work in the DEE.

The fundamental issue of designing programs for training scientific and pedagogical personnel at $\mathrm{PhD}$ degree courses is the question of universality. Universalism in most sources is interpreted through the concept of "comprehensiveness", which emphasizes the priority of fundamental knowledge for a person, his life and activities in the modern complex world, harmony with nature and with himself. Universalism is understood as "versatility (in knowledge, skills, etc.), diversity, and the multiplicity of something" [22].

Universalism emerged as an organized movement in North America during the Enlightenment. Dr. George de Benville, a descendant of French Huguenots who moved to Pennsylvania in 1741, helped spread universalist views. John Murray (1741-1815), who arrived from England in 1770, also widely preached this faith and in 1779 founded the first universalist Church in Gloucester, Massachusetts. He later became a Minister in the universalist congregation in Boston. Many Baptists joined the universalist Church, including the preachers of E. Winchester (1751-1797), who roamed the United States and Canada, and C. Rich is from New England. Universalists were among the first to apply religious principles to solving social problems. The great interest of universalists in the Affairs of education was shown in the Foundation of several American colleges. The most famous of them are Taft University in Medford (Massachusetts, 1852) and St. Lawrence University in Canton (new York, 1856).

Scientific knowledge is objective knowledge, independent of any subjective interests and opinions, it is knowledge that is logically verified, reasoned, and verifiable. This is the kind of knowledge that physics, or rather mechanics, demanded by the development of the industrial revolution and machine civilization, provided during Lichtenberg's time. 
Therefore, experimental physics, which operated with precise, experimentally verified facts (which is exactly what Lichtenberg was doing), acted as the ideal of science as such, the ideal of intelligence. The Humanities did not meet the criteria of a rigorous science based on facts, and so until the end of the 19th century. it had no scientific status. So, in classical science, a fact was understood as an event independent of a person, as a fragment of objective reality that is described, measured, calculated, generalized, and which act as the "data" of science, as the basis of true knowledge.

However, since the end of the 19th century, the situation has changed significantly: society has reached such a degree of development that people no longer feel part of the world, subject to its laws. Man became more and more aware of his ability to transform, to create the world and himself. As science itself became more complex, the role of theoretical knowledge, which already covered large volumes of empirical data, constantly increased, and therefore scientists were forced to develop complex procedures for processing knowledge - abstraction, generalization, systematization, comparison, description, explanation, etc. Facts became scientific as they were processed by various theoretical procedures, considered as fitting into certain pictures of the world, worldview systems. By itself, the "naked fact" no longer said anything, did not explain anything.

From the point of view of the researcher A.Yu. Tsofnas, the methodological approach of interpretation: "Universalism as a fairly strict scientific concept is possible through methodological elaboration of its structural and ontological foundations." The author suggests the most "short and constructive" way to achieve the goal. That «...the way to use the existing interdisciplinary concept in universalism, ... the synthesis of universalism with one of the variants of the system - wide theory-parametric systems theory" [22].

"Universalism as a fairly strict scientific concept is possible through methodological elaboration of its structural and ontological foundations."

Special importance, as shown by the research, for ensuring the quality of development and application of a universally oriented educational program for training scientific and pedagogical personnel at $\mathrm{PhD}$ degree courses belongs to the issues of designing the content of education. New conceptual and theoretical and methodological approaches are needed to structure the content of training programs for scientific and pedagogical personnel, to design appropriate technologies for mastering them at the level of the academic discipline, module, and the entire program as a whole. It is also important to choose the basis for classifying the knowledge that is the core of the content of postgraduate training, to determine the procedures for taxonomizing the levels of their assimilation, and to assess the quality.

When organizing the training of scientific and pedagogical personnel, it is important to take into account the efficiency factor. This efficiency appears to be a very complex and ambiguous phenomenon. In the course of managing the process of its provision and evaluation, it is important to take into account a set of measures for managing and selfmanaging the activities of students; the content and technologies of training; ways to motivate effective work of $\mathrm{PhD}$ students and research supervisors. Special attention should also be paid to the selection of appropriate criteria and indicators. The process of performance management involves the mandatory definition and specification of the final results of the implementation of postgraduate programs in the form of measurable competencies. In this case, it is important to ensure a balance between universality and the availability of applied knowledge, skills, and abilities for future professional purposes [2326].

To determine the effectiveness of our universal-oriented educational program for training scientific and pedagogical personnel at $\mathrm{PhD}$ degree courses by using the tools of the digital educational environment in the research process, a program was developed and a pedagogical experiment was conducted for three years. The idea of the experiment was to 
test the effectiveness of the developed experimental program in comparison with the previously used, traditional one.

At the first stage of the experiment, a number of diagnostics and evaluation activities of post-graduate students who were enrolled in training programs developed in the traditional form in accordance with the "Federal state educational standard of higher education. The level of higher education. Training of highly qualified personnel. Direction of training 44.06.01 Education and pedagogical Sciences" were conducted twice, at the end of the second year of training, to identify the degree of formation of a number of key universal competencies.

The competence assessment procedure includes formative and ascertaining activities that result in intermediate or final assessments. As a result of the assessment and diagnostic activities carried out over two years, a large array of data was obtained. In this scientific study, we present the results of the final evaluation and diagnostic event.

The criteria assessment procedure was conducted with different groups of graduate students. At this stage, it was supposed to assess the level at the end of the training stage, taking into account the completed final certification tests.

When preparing the final evaluation and diagnostic material, it is necessary to carefully select criteria to improve the accuracy of measuring the level of achievement of each participant. It is advisable to use a wide range of criteria containing a description descriptor.

Group A consisted of 25 post-graduate students, group B consisted of 26 post-graduate students. Also, for a comparative assessment, a group B was formed from teachers who did not study in graduate school.

Assessment of competencies in the self-assessment mode and expert survey was carried out using a four-level scale that reflects the level of expression (significance) of a particular competence:

1 point - insignificant, insignificant level; 2 - weak; 3 - significant; 4-strong.

The subjects of the expert survey were representatives of the teaching staff who conduct classes with graduate students, are involved in the work of commissions for the admission of candidate exams, scientific supervisors on the topics of dissertation research of graduate students, as well as outstanding representatives of science.

The results of evaluation and diagnostics are presented in table 1 .

The data in table 1 clearly demonstrate a more or less noticeable increase in values (the correlation is from 0.15 to 0.53 ) for all universal competencies without exception in graduate students of both groups at the end of the second year of training compared to teachers who have completed bachelor's, master's or specialty programs.

The explanation for this is that the process of two years of postgraduate study involves a number of factors that contribute to the development of universal competencies:

- $\quad$ passing training courses "History and philosophy of science", "Foreign language", preparing essays and passing candidate exams;

- selection of the topic, study and analysis of literary sources, the state of the problem in educational and pedagogical practice, preparation of materials for the dissertation; forums);

- presentations at various scientific and practical events (seminars, conferences,

- preparation and publication of own research results in the form of articles and abstracts;

- performing various tasks, functions of assignments at the Department, conducting training sessions with students in the framework of pedagogical practice;

- etc.

The idea of the experiment, at its second stage, also provided for fixing the universal competencies shown in table 1 for post-graduate students who studied under an 
experimental educational program developed in accordance with the Federal state educational standard of higher education. The level of higher education. Training of highly qualified personnel. Direction of training 44.06.01 Education and pedagogical science.

Table 1. Results of diagnostics and assessment of the level of development of key universal competencies in graduate students who were engaged in the experimental program during the third year of training (scores on a 4-point scale).

\begin{tabular}{|c|c|c|}
\hline Universal competence discripts & $\begin{array}{l}\text { Results } \\
\text { Group A }\end{array}$ & $\begin{array}{l}\text { Results } \\
\text { Group B }\end{array}$ \\
\hline Formation of productive cooperation skills (self-assessment) & $\begin{array}{l}3,86 \\
(+0,53)\end{array}$ & $\begin{array}{l}3,80 \\
(+0,47)\end{array}$ \\
\hline Formation of professional success (self-assessment) & $\begin{array}{l}5,04 \\
(+0,27)\end{array}$ & $\begin{array}{l}5,01 \\
(+0,34)\end{array}$ \\
\hline $\begin{array}{l}\text { Ability to perform systematic and multi-stage scientific work that } \\
\text { allows achieving the set results (external expert assessment) }\end{array}$ & $\begin{array}{l}4,95 \\
(+0,15)\end{array}$ & $\begin{array}{l}4,98 \\
(+0,16)\end{array}$ \\
\hline Readiness for subject-language integration (self-assessment) & $\begin{array}{l}4,93 \\
(+0,33)\end{array}$ & $\begin{array}{l}4,90 \\
(+0,40)\end{array}$ \\
\hline Readiness for subject-philosophical integration (self-assessment) & $\begin{array}{l}4,90 \\
(+0,39)\end{array}$ & $\begin{array}{l}4,86 \\
(+0,28)\end{array}$ \\
\hline $\begin{array}{l}\text { Validity and reliability of independent research results (external } \\
\text { expert assessment) }\end{array}$ & $\begin{array}{l}4,68 \\
(+0,35)\end{array}$ & $\begin{array}{l}4,71 \\
(+0,38)\end{array}$ \\
\hline $\begin{array}{l}\text { Ability to critically analyze research activities (external expert } \\
\text { assessment) }\end{array}$ & $\begin{array}{l}4,65 \\
(+0,27)\end{array}$ & $\begin{array}{l}4,67 \\
(+0,29)\end{array}$ \\
\hline $\begin{array}{l}\text { Knowledge-intensive methods of information retrieval (self- } \\
\text { assessment) }\end{array}$ & $\begin{array}{l}4,69 \\
(+0,35)\end{array}$ & $\begin{array}{l}4,63 \\
(+0,34)\end{array}$ \\
\hline $\begin{array}{l}\text { Readiness to use information modeling methods and tools (external } \\
\text { expert assessment) }\end{array}$ & $\begin{array}{l}5,15 \\
(+0,25)\end{array}$ & $\begin{array}{l}5,16 \\
(+0,28)\end{array}$ \\
\hline $\begin{array}{l}\text { Readiness to systematize educational technologies based on the } \\
\text { dominant focus on modern educational results (external expert } \\
\text { assessment) }\end{array}$ & $\begin{array}{l}4,72 \\
(+0,39)\end{array}$ & $\begin{array}{l}4,70 \\
(+0,37)\end{array}$ \\
\hline $\begin{array}{l}\text { Ability to adapt to the requirements of the discipline and the teacher } \\
\text { implementing it in the higher education system (external expert } \\
\text { assessment) }\end{array}$ & $\begin{array}{l}4,32 \\
(+0,35)\end{array}$ & $\begin{array}{l}4,38 \\
(0,34)\end{array}$ \\
\hline Basic knowledge in various fields (self-assessment) & $\begin{array}{l}5,95 \\
(+0,14)\end{array}$ & $\begin{array}{l}5,98 \\
(+0,16)\end{array}$ \\
\hline Problem solving (external expert assessment) & $\begin{array}{l}3,93 \\
(+0,33)\end{array}$ & $\begin{array}{l}43,90 \\
(+0,41)\end{array}$ \\
\hline Reflexive abilities (external expert assessment) & $\begin{array}{l}4,98 \\
(+0,49)\end{array}$ & $\begin{array}{l}4,76 \\
(+0,38)\end{array}$ \\
\hline Ability to adapt to new situations (self-assessment) & $\begin{array}{l}4,12 \\
(+0,25)\end{array}$ & $\begin{array}{l}4,56 \\
(+0,20)\end{array}$ \\
\hline
\end{tabular}

Note: the values of the increase in the level of competence development in comparison with the values given in table 1 for teachers who did not study in graduate school (group B) are shown in parentheses.

The participants of this stage of the experiment were 13 post-graduate students of the third year of training, who, after the end of the second year of training, were transferred to training in accordance with the above-mentioned Federal state educational standard. The results of their self-assessments and external expert evaluations are shown in table. 2. 
Table 2. Results of diagnostics and assessment of the level of development of key universal competencies in graduate students who were engaged in the experimental program during the third year of training (scores on a 4-point scale).

\begin{tabular}{|l|l|l|}
\hline Universal competence discripts & $\begin{array}{c}\text { Results of } \\
\text { the } \\
\text { original }\end{array}$ & $\begin{array}{l}\text { Final } \\
\text { result }\end{array}$ \\
\hline Formation of productive cooperation skills (self-assessment) & 3,97 & 4,80 \\
\hline Formation of professional success (self-assessment) & 5,05 & 5,90 \\
\hline $\begin{array}{l}\text { Ability to perform systematic and multi-stage scientific work that } \\
\text { allows achieving the set results (external expert assessment) }\end{array}$ & 4,27 & \\
\hline Readiness for subject-language integration (self-assessment) & 4,50 & 5,32 \\
\hline Readiness for subject-philosophical integration (self-assessment) & 3,78 & 4,44 \\
\hline $\begin{array}{l}\text { Validity and reliability of independent research results (external } \\
\text { expert assessment) }\end{array}$ & 4,56 & 5,23 \\
\hline $\begin{array}{l}\text { Ability to critically analyze research activities (external expert } \\
\text { assessment) }\end{array}$ & 4,61 & 5,78 \\
\hline $\begin{array}{l}\text { Knowledge-intensive methods of information retrieval (self- } \\
\text { assessment) }\end{array}$ & 4,01 & 5,31 \\
\hline $\begin{array}{l}\text { Readiness to use information modeling methods and tools (external } \\
\text { expert assessment) }\end{array}$ & 4,04 & 5,43 \\
\hline $\begin{array}{l}\text { Readiness to systematize educational technologies based on the } \\
\text { dominant focus on modern educational results (external expert } \\
\text { assessment) }\end{array}$ & 4,92 & 6,02 \\
\hline $\begin{array}{l}\text { Ability to adapt to the requirements of the discipline and the teacher } \\
\text { implementing it in the higher education system (external expert } \\
\text { assessment) }\end{array}$ & 4,0 & 4,69 \\
\hline Basic knowledge in various fields (self-assessment) & 3,86 & 4,87 \\
\hline Problem solving (external expert assessment) & 3,12 & 4,12 \\
\hline Reflexive abilities (external expert assessment) & 5,12 & 5,74 \\
\hline Ability to adapt to new situations (self-assessment) & 5,18 & 5,02 \\
\hline
\end{tabular}

As follows from table 2, significant increases in the values of all diagnosed competencies were recorded during postgraduate studies, especially during the period of training in an experimental universal-oriented educational program. In our opinion, this is the result of a complex of factors generated by the process of implementing the pilot program and, first of all, such factors as:

- $\quad$ study of integrative, interdisciplinary disciplines, modules;

- $\quad$ shifting the emphasis in the ideology of the educational process to the competence aspects of learning outcomes;

- use of efficient, universal-oriented and digital, network technologies;

- use of digital educational environment in the educational process (discrete lectures, Internet conferences, forums, blogs, etc;

- inclusion in the variable part of the postgraduate program of a number of enriching, integrating disciplines, modules that determine the success of a graduate in the professional field;

- formation of individual curricula, new approaches to educational process management, promotion and provision of educational services in the digital educational environment;

- $\quad$ learning in a variety of environments and spaces, including networking;

- $\quad$ saturation of practice programs with tasks of an interdisciplinary, problem-oriented nature, involving a significant proportion of independent work;

- focus in research on solving a complex problem. 
Thus, the results of the pedagogical experiment confirmed initially put forward in the development of the program hypothesis that the design and application of the system of training scientific-pedagogical personnel of universal-oriented programs using tools of the digital educational environment promotes the formation of a modern, successful, effective specialist generic type that is able to solve professional tasks in a wide range associated with troubles, uncertainty, high $\mathrm{R} \& \mathrm{~d}$ expenses that meet the needs of the digital economy.

\section{Conclusions}

The implementation of the main professional educational programs of higher education programs for training scientific and pedagogical personnel in postgraduate studies is to create a more or less formal structure of doctoral education, that is, to move from the traditional "apprenticeship model" to a more structured research education and training within disciplinary or interdisciplinary programs, or postgraduate schools of postgraduate studies [8]. The defining characteristic of such an educational program is the overlap of two complementary processes: the acquisition of professional research experience and personal development of the post-graduate student, aimed at the formation of universal and digital competencies.

E.V. Zasypkina suggests combining theoretical and practical design between science and practice through practice-oriented activities with the help of scientific knowledge and generalization of experience to promote science [27].

The key factors for the success of modern programs for training scientific and pedagogical personnel in graduate school with the qualification "Researcher. Teacherresearcher" are:

- formation of universal / transferable and digital (i.e. preserving their value even outside the context of academic research) competencies that can be implemented in any field of activity where the student continues his professional development (including beyond the academic career);

- developed opportunities for communication between teachers, postgraduates, students and researchers involved in various forms of interaction.

Issues related to the organization and training of highly qualified teachers in digital learning do not require separate, practice-oriented developments, but a comprehensive solution that has a holistic nature and represents a multi-level training of teachers, from bachelor to University teacher, to professional activities in digital learning based on special principles with a description of its specific pedagogical technologies.

\section{References}

1. V.A. Slastenin, L. S. Podymova, Siberian Pedagogical Journal, 1, $42-49$ (2007)

2. A.M. Kondakov, A.A. Kostyleva, RUDN Journal of Informatization in Education, 16(4), 295-307 (2019)

3. M.S. Yanitskiy, Professional Education in Russia and Abroad, 2(34), 38-44 (2019)

4. A.V. Vershinina, E.N. Koshkina, E.R. Orlova, M.V. Koshkin Analysis of the training system for the digital economy in Russia. - Konf., p. 13-15 (Simferopol-Alushta, May 30-June 01, 2019)

5. I.V. Robert, Electronic libraries, 23 (1-2), 145-164 (2020)

6. I.V. Robert, Man and education, 2, 165-174 (2017)

7. I.V. Robert, Pedagogical Informatics, 3, 27-41 (2015) 
8. A.A. Verbitsky, Digital training: problems, risks and prospects (Homo Cyberus, Moscow, 2019)

9. A.V. Darinsky, Continuing education (Soviet pedagogy, Moscow, 1975)

10. V.P. Zinchenko, Pedagogy 5, 3-6 (1998)

11. A.M. Novikov Post-industrial education, p. 136 (Moscow: Agves, 2008)

12. A.M. Novikov Methodology of education, p. 420 (Moscow: Agves, 2006)

13. S.D. Karakozov, Academic Council, 9, 63-64 (2005)

14. I.F. Berezhnaya, Training of highly qualified personnel: problems and their solutions. (Proceedings of Voronezh State University. Series: Problems of higher education, Voronezh, 2018)

15. I.F. Berezhnaya, Science and business: ways of development, 2(08), $42-48$ (2012)

16. N.V. Nikulicheva, Interactive education, 3, 16-20 (2019)

17. M. Vayndorf-Sysoeva, N. Kuznetsov, R. Drazhan, In:Bulletin of the Moscow Region State University. Series: Pedagogics, 4, 70-82 (2018)

18. M.E. Vayndorf-Sysoeva, M.L. Subocheva, In: Bulletin of the Moscow Region State University. Series: Pedagogics, 3, 25-36 (2018)

19. M.E. Vayndorf-Sysoeva, M.L. Subocheva, Model of multilevel teacher training for professional activities in the context of digital learning (Homo Cyberus, Moscow, 2019)

20. I.A. Zimnyaya, Experiment and innovation in school, 2, 7-14 (2009)

21. O.Yu. Zaslavskaya, RUDN Journal of Informatization of Education, 14 (3), 309-316 (2017)

22. A. I. Zofnas Teoriya system t teoriya poznaniy, p. 308 (Odessa: Astroprint, 1999)

23. V.D. Shadrikov, Vestnik Yaroslavskogo gosudarstvennogo universiteta imeni P.G. Demidova. Seriya Psikhologiya, 1, 15-21 (2006)

24. V.D. Shadrikov, Sibirskii uchitel', 6, 5-15 (2007)

25. V.V. Belkina, Yaroslavl Pedagogical Bulletin, 5, 117-126 (2018)

26. O.A. Stepanov, Journal of Russian law, 11, 107-111. (2018)

27. E.V. Zasypkina, Bulletin of the Chelyabinsk state pedagogical University, 1, 27-34 (2008) 